ELORE (ISSN 1456-3010), vol. $16-2 / 2009$.

Julkaisija: Suomen Kansantietouden Tutkijain Seura ry.

[http://www.elore.fi/arkisto/2_09/ajankoht_kurvinen_timonsaari_2_09.pdf]

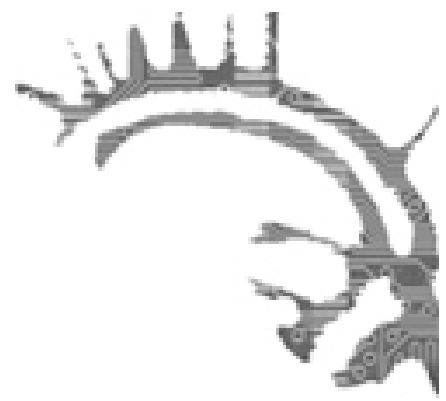

\title{
Ajankohtaista
}

\section{KULTTUURINTUTKIJAT ELÄMÄNTARINOIDEN ÄÄRELLÄ}

XIV Kulttuurintutkimuksen seminaari Elämäntarina - elinkaari Oulun yliopistossa 23.24.4.2009

\section{Heidi Kurvinen ja Niina Timosaari}

Oulun yliopistossa järjestettiin 23.-24.4.2009 järjestyksessään 14. kulttuurintutkimuksen seminaari, joka kokosi Ouluun pienen mutta sitäkin innokkaamman joukon eri-ikäisiä tutkijoita. Seminaarin teemana oli tällä kertaa elämäntarinat ja elinkaaret, ja se toteutettiin yhdessä Suomen Elämäntarinayhdistyksen kanssa.

Kutu-seminaarin pääpuhujat edustivat monipuolisesti sekä tieteen että elämäntarinoiden harrastajien näkökulmia. Ensimmäisen seminaaripäivän avanneessa työryhmässä Suomen Elämäntarinayhdistys ry:n puheenjohtaja Anja Vähäaho esimerkiksi kertoi jouhevan tarina vuonna 1999 perustetun yhdistyksen vaiheista. Kasvatustieteen professori Leena Syrjälä puolestaan jatkoi otsikolla Tutkijana ja opettajana elämäntarinan äärellä. Syrjälä kiinnitti puheenvuorossaan huomiota muun muassa elämäntarinoiden pirstaleisuuteen. Hänen mukaansa "elämä on elettyjen, koettujen ja kerrottujen tarinoiden kudelma, jota kerrotaan usein lähtöinä ja palasina". Mieleen jäi myös Syrjälän huomio siitä, että kertomus voi olla muutakin kuin teksti.

Avajaispäivän mielenkiintoisimman puheenvuoron esitti kuitenkin naistutkimuksen yliopistoverkoston lehtori Tuija Saresma. Elämän kertomisen kolmiota käsitelleessä alustuksessaan Saresma esitteli perinteisen subjektista, elämästä ja kerronnasta muodostuvan kolmion sijasta subjektista, lukijoista ja kerronnan toisista muodostuvan kolmiomallin. Saresman mukaan tarinaa ei kerrota koskaan tyhïössä vaan elämäntarinan toiset ovat siinä mitä moninaisimmin tavoin läsnä. Lukijoille elämäntarinat ja niiden toiset tarjoavat mahdollisuuden samaistumiseen ja erontekoon. 


\section{TYÖRYHMIÄ TEATTERISTA PÄIVÄKIRJOIHIN JA TUTKIJAN VALTAAN}

Pääpuhujien lisäksi elämäntarinan ja elinkaaren -teemaa käsiteltiin seminaarissa kuudessa työryhmässä. Teatteriin, musiikkiin, päiväkirjoihin sekä maisemiin ja paikkoihin liittyneissä ryhmissä pidettiin yhteensä 24 alustusta, joissa seminaarin teemaa lähestyttiin mitä moninaisimmista näkökulmista. Allekirjoittaneiden johtamassa työryhmässä elämäntarinoita tarkasteltiin tutkijan vallan näkökulmasta. Lähtökohtana oli ajatus siitä, että tutkija käyttää aina valtaa tuottaessaan tieteellistä tietoa.

Feministisen tutkimuksen piirissä tutkijan valtaa on pohdittu jo pitkään ja oman position reflektoiminen kirjoitetaan usein näkyviin varsinaiseen tutkimukseen. Kaikki tieteenalat eivät ole kuitenkaan yhtä tietoisia tutkijan positioon liittyvistä valta-aspekteista, mikä näkyi myös koolle kutsutussa työryhmässä. Kirjallisuutta, pohjoismaista filologiaa ja kasvatustieteitä edustaneet alustajat lähestyivät työryhmän teemaa hyvin erilaisista lähtökohdista ja erilaisin tavoin.

Työryhmän aloitti kirjallisuudentutkija Marjatta Fyrstén, joka käsitteli esitelmässään runoilija Impi Kauppilan elämäkerran kirjoittamista. Fyrstén paikansi tutkimuksensa feministisen tutkimuksen kenttään ja kertoi tutkimuksellaan olevan emansipatorisia pyrkimyksiä. Tällaisiksi hän mainitsi esimerkiksi marginalisoidun runoilijan nostamisen tutkimuksen keskiöön. Tutkijan valtansa Fyrstén paikansi ennen kaikkea päätösvaltaansa valita, mitä hän kertoo ja jättää kertomatta Kauppilan elämästä. Lisäksi hän pohti, onko tutkijalla oikeutta kertoa sellaisen henkilön elämäntarina, joka "on halunnut elää ja kuolla tuntemattomana”. Alustuksen jälkeisessä keskustelussa Fyrsténiltä kysyttiin muun muassa sitä, miten hän on valinnut tutkimuksessa analysoimansa runot sekä minkälaisin perustein hän on kertonut tai jättänyt kertomatta asioita Kauppilan elämästä. Varsinaisessa alustuksessa nämä kysymykset olivat jääneet auki, mutta loppukeskustelussa tutkija kertoi kirjoittaneensa valinnat auki jo valmistuneeseen tutkimukseensa.

Työryhmän toisena alustajana oli pohjoismainen filologi Tuula Jurmu, joka puhui tekeillä olevasta väitöskirjastaan otsikolla Munttuva kielellinen identiteetti - PobjoisPobjanmaalta läbteneen suvun tapaustutkimus. Tutkimus kartoittaa erään suvun ja sen jäsenten kielellistä identiteettiä. Jurmun alustus oli tutkijan vallan näkökulmasta hyvin mielenkiintoinen, sillä hän kuuluu tutkimaansa sukuun. Jurmu käsittelikin alustuksessa tutkijan ja tutkimuskohteen läheisyyteen liittyviä positiivisia näkökulmia. Sukulaissuhteesta mahdollisesti aiheutuviin haasteisiin hän ei sen sijaan kiinnittänyt huomiota. Alustuksen jälkeisessä keskustelussa pohdittiinkin sitä olisiko Jurmun mahdollista kirjoittaa itsensä tutkijana osaksi tutkimustaan ja reflektoida omaa positiotaan läpi työn. Lisäksi mietimme haastateltavien anonymiteetin merkitystä. Pyrkimys häivyttää tapaustutkimuksen kohteena oleva suku näkyvistä tuntui keskustelijoista ongelmalliselta, koska tutkijan oman position esiintuomista pidettiin tärkeänä. Se kuitenkin mahdollistaisi kohteena olevan suvun identifioimisen, vaikka sukua ei tutkimuksessa suoraan tuotaisikaan esiin. 
Työryhmän viimeisenä alustajana oli kasvatustieteilijä Teemu Suorsa, joka puhui Stefan Bussen, Christiane Ehsesin ja Rainer Zechin kehittämästä kollektiivisesta elämäntarinatutkimuksesta subjektitieteellisenä metodina. Tässä metodissa elämäntarina ei ole tutkimuksen tulos vaan sen lähtökohta, ja elämäntarinan kertoja on mukana sen tulkinnassa. Käytännössä prosessi etenee siten, että elämäntarina tuotetaan haastattelussa, jonka haastateltava litteroi. Sen jälkeen tarinasta keskustellaan ryhmässä ja elämäntarinan kertoja tiivistää tämän keskustelun jälleen kirjalliseen muotoon. Tavoitteena prosessissa on jäsentyneempi käsitys omasta elämästä ja toimintakykyisyydestä.

Suorsan alustuksen jälkeinen keskustelu ei ollut niin vilkasta kuin aikaisemmin. Syynä tähän oli varmasti se, että subjektitieteellinen psykologia ei avautunut ihan helposti psykologiaan perehtymättömälle. Alustuksessa esitetty kollektiivisen elämätarinatutkimuksen menetelmä herätti kuitenkin kiinnostusta ja pohdintoja siitä, olisiko sitä mahdollista hyödyntää muiden tieteenalojen piirissä.

Kokonaisuudessaan tutkijan valtaa käsitellyt työryhmä lunasti alustajien vähäisestä määrästä huolimatta paikkansa seminaarin työryhmien joukossa. Toisistaan selkeästi poikenneet alustukset herättivät vireää mielipiteidenvaihtoa ja avasivat sekä alustajille että kuuntelijoille uusia näköaloja tutkijan vallan pohtimiseen.

Filosofian maisterit Heidi Kurvinen ja Nina Timosaari valmistelevat väitöskirjojaan Oulun yliopistossa. 